\title{
OPEN Characterization of a Bowman-Birk type trypsin inhibitor purified from seeds of Solanum surattense
}

\author{
Abhijeet P. Herwade ${ }^{1}$, Sainath S. Kasar ${ }^{1,2}$, Niraj R. Rane ${ }^{3}$, Shadab Ahmed ${ }^{4}$, \\ Jaswinder Singh Maras ${ }^{5}$ \& Pankaj K. Pawar ${ }^{6 \bowtie}$
}

\begin{abstract}
A Bowman-Birk type trypsin inhibitor protein (SSTI) from seeds of the medicinal plant Solanum surattense was isolated, purified and characterized. SSTI showed a single band on SDS-PAGE corresponding to $11.4 \mathrm{kDa}$ molecular weight. It is a glycoprotein ( $2.8 \%$ glycosylation) that differentially interacted with trypsin and chymotrypsin in a concentration-dependent manner. Its peptide sequence is similar to other Bowman-Birk type protease inhibitors found in Glycine max and Phaseolus acutifolius. The inhibitory activity was stable over a wide range of $\mathrm{pH}(1-10)$ and temperatures $\left(10-100^{\circ} \mathrm{C}\right)$. Far-UV Circular Dichroism (CD) studies showed that SSTI contains $\beta$ sheets $(\sim 23 \%)$ and $\alpha$ helix $(\sim 6 \%)$ and demonstrated structural stability at wide $\mathrm{pH}$ and high temperature. The kinetic analysis revealed a noncompetitive (mixed) type nature of SSTI and low inhibitor constant (Ki) values $\left(16.6 \times 10^{-8} \mathrm{M}\right)$ suggested strong inhibitory activity. Isothermal titration calorimetric analysis revealed its high affinity towards trypsin with dissociation constant $\left(K_{d}\right) 2.28 \mu \mathrm{M}$.
\end{abstract}

Biotic stress induces the generation and accumulation of phenolic compounds and pathogenesis-related (PR) proteins which subsequently prevent an invasion of pests like insects and microbial pathogens ${ }^{1}$. Most of the plant PR proteins are acid-soluble, low molecular weight and protease enzyme inhibitors ${ }^{2,3}$. Protease inhibitors are mainly harbored by four plant families' viz. Fabaceae, Gramineae, Leguminosae, and Solanaceae ${ }^{4,5}$. Plant protease inhibitors (PPIs) are categorized as serine, cysteine, threonine, aspartic and metallo-protease inhibitors based on their interaction with specific amino acid(s) present in the active site of protease ${ }^{4}$. On the basis of protein sequence and structural properties; PPIs are subdivided into 10 families' as (1) Kunitz (serine) protease inhibitors; (2) Bowman-Birk (serine) protease inhibitors; (3) metallocarboxy protease inhibitors; (4) cysteine protease inhibitors; (5) cereal trypsin/ $\alpha$-amylase inhibitors; (6) potato type I; (7) potato type II protease inhibitors; (8) squash inhibitors; (9) serpins and (10) mustard trypsin inhibitors ${ }^{6}$. The molecular masses of Kunitz inhibitors are relatively high $(\sim 20,000 \mathrm{da})$ and possesses a single reactive site specific for trypsin. The Bowman-Birk inhibitors (BBIs) are a low molecular weight proteins ( $9000 \mathrm{da})$, heat stable, double-headed and capable of inhibiting two serine proteases trypsin and chymotrypsin independently or simultaneously ${ }^{7}$.

PPIs are usually distributed in plant tissues; particularly; in the seeds and tubers along with leaves, flowers and fruits and protect the host from the attack of various insects ${ }^{8,9}$. Protease inhibitors (PIs) are produced in the plants' endogenous defense system and expressed under various stress conditions such as attack by pathogens and insects, wounding and exposure to various environmental factors like salinity, heavy metals and temperature variations ${ }^{5}$. Most PIs interact with the specific active site of target proteases at the catalytic domain forming a stable protease inhibitor complex and there by inhibits the activity through competitive or non-competitive mode of action. The PIs are evolved as anti-metabolic proteins to control the growth of pathogens and insect pests as such proteins form requisite interaction with proteases of pathogens there by breaking down the supply of essential amino acids most needed by the pathogen for its survival ${ }^{10}$. The economically vital classes of pests like Lepidoptera, Diptera and Coleoptera use serine and cysteine type proteases in their digestive system. In the light of these facts, inhibitor(s) of serine proteases (trypsin/chymotrypsin) in insect diet is a wise approach to investigate its/their adverse effects on growth and development of economically important pests. The applications

${ }^{1}$ Department of Biotechnology, Shivaji University, Kolhapur, MS 416004, India. ${ }^{2}$ Department of Biochemistry, School of Life Sciences, Kavayitri Bahinabai Chaudhari North Maharashtra University, Jalgaon, MS 425001, India. ${ }^{3}$ Biochemistry Division, Department of Chemistry, Savitribai Phule Pune University, Pune, MS 411007, India. ${ }^{4}$ Institute of Bioinformatics and Biotechnology, Savitribai Phule Pune University, Pune, MS 411007, India. ${ }^{5}$ Department of Molecular and Cellular Medicine, Institute of Liver and Biliary Science, New Delhi 110070, India. ${ }^{6}$ Department of Biochemistry, Shivaji University, Kolhapur, MS 416004, India. ${ }^{\square}$ email: pkp.biochem@ unishivaji.ac.in 


\begin{tabular}{|l|l|l|l|l|l|}
\hline Steps & Total protein $(\mathbf{m g})$ & Total activity $($ TIU) & Specific activity (TIU/mg) & Yield \% & Fold purification \\
\hline Crude extract & 860 & 9971 & 11.5 & 100 & 1 \\
\hline After dialysis & 475.2 & 6078 & 13 & 55 & 1.2 \\
\hline Ion exchange chromatography & 4.83 & 498 & 103.1 & 0.56 & 9 \\
\hline
\end{tabular}

Table 1. Purification profile of SSTI. Total amount of protein extracted from $10 \mathrm{~g}$ of fine powder of dried seeds of S. surattense. TIU (trypsin inhibitory activity unit) was defined as the decrease in 0.01 unit of absorbance at $410 \mathrm{~nm}$.

of inhibitors of proteases and $\alpha$-amylases are well documented and they are considered to be one of the important tools in pest management strategies ${ }^{11,12}$. PPIs have various biological applications including apoptosis, hormone processing and blood clotting and PIs are also being studied on various parasitic or viral diseases including malaria, schistosomiasis, colds, flu', dengue etc ${ }^{13}$.

A vast number of plants belonging to family Solanaceae are reported for the presence of proteinaceous protease inhibitors. To quote a few such as Ipomoea batatas (sweet potato), Solanum tuberosum (potato), Solanum palustre and Solanum nigrum have been studied extensively ${ }^{14-16}$. As per our literature survey, there is no report on the presence of PI in Solanum surattence (Syn. S. virginianum), a medicinally important member of family Solanaceae though this plant was previously reported for various biological applications ${ }^{17-19}$. Biochemical characterization and specificity of inhibition is an important step towards the discovery of an inhibitor and evaluate its/their potential. Present study reports isolation, purification and characterization of a Bowman-Birk type proteinaceous trypsin inhibitor from the seeds of Solanum surattence.

\section{Results and discussion}

Purified SSTI is a low molecular weight monomeric protein. Proteinaceous trypsin inhibitor (SSTI) was successfully isolated and purified from the seeds of Solaum surattense. About ninefold purification of SSTI was achieved through three steps protein purification method, (1) crude extract preparation; (2) partial purification of protein through ammonium sulphate precipitation followed by dialysis and (3) cation exchange column chromatography. The activity guided protein purification strategy was used for exact purification. The active concentrated fraction was utilized for further analysis. The drawn purification profile showed that about $0.56 \%$ yield of SSTI was obtained with $103.1 \mathrm{TIU} / \mathrm{mg}$ of trypsin inhibitory specific activity (Table 1). Previously, Ee et al. ${ }^{20}$ achieved a $0.54 \%$ yield of purified kunitz-type trypsin inhibitor from Acacia victoriae (Bentham) seeds. In couple of earlier studies on isolation of trypsin inhibitors from maize and sorghum achieved 4.96 and 5.78 fold purification respectively ${ }^{21}$. while about 12 fold purification of PI from the culture supernatant of Streptomyces spp. was obtained by Marathe et al. ${ }^{22}$ with a similar process as used for SSTI purification.

The homogeneity of isolated active protein fraction was analyzed by SDS-PAGE in presence of $\beta$-mercaptoethanol (reducing conditions) and a single protein band having a molecular mass of approximately $12 \mathrm{kDa}$ was observed when compared with the standard molecular weight protein markers (Fig. 1A and Supplementary Figure S2A). This was further confirmed by Sephadex G-50 gel permeation chromatography where it was eluted as a single peak with $11.4 \mathrm{kDa}$ molecular mass when log molecular masses of known proteins were plotted against the ratio of elution volume of protein peak and void volume (Figure S1). Single polypeptide chain and monomeric protein PIs of $18.9 \mathrm{kDa}$ and $23.6 \mathrm{kDa}$ molecular weight are earlier reported from the seeds of Pithecellobium dumosum and leaf extract of Moringa oleifera respectively ${ }^{23,24}$. Generally, the molecular mass range of PI is from less than $10-50 \mathrm{kDa}$ and depends on the source ${ }^{22}$. Relatively low molecular weight of SSTI is in complete agreement with the hypothesis that the serine protease inhibitors from the plant are small proteinaceous entities with low molecular weight $(3 \text { to } 25 \mathrm{kDa})^{5}$.

SSTI is a glycoprotein. SSTI was proved to be a glycoprotein in nature as confirmed by reaction with Schiff's reagent (PAS staining) on SDS-PAGE (Fig. 1B and Supplementary Figure S2B). The development of a magenta-colored single band was suggestive of the presence of glycan moiety in SSTI. Total carbohydrate content was quantitatively determined using phenol-sulfuric acid reagent and it was observed that SSTI contains $2.8 \%$ carbohydrate moieties in it. Solanum tuberosum, another member of family Solanaceae, is reported for glycosylated proteinaceous PI by Shah et al. ${ }^{25}$ while plants viz. Swartzia pickellii, Peltophorum dubium, Echinodorus paniculatus and Acacia victoriae from other families are also characterized by the presence of glycoprotein $\mathrm{PI}^{26-29}$.

SSTI differentially interacted with different proteases. The concentration-dependent inhibition study involved the pre-incubation of various proteolytic enzymes (trypsin, chymotrypsin, proteinase $\mathrm{k}$, and subtilisin) with increasing concentrations of SSTI $(10-50 \mu \mathrm{g} / \mathrm{ml})$. It was revealed that, SSTI could only inhibit trypsin and chymotrypsin among the four proteases. At $10 \mu \mathrm{g} / \mathrm{ml}$ concentration, SSTI inhibited the activity of trypsin and chymotrypsin by $18.14 \%( \pm 0.78)$ and $11.40 \%( \pm 1.54)$, respectively. The highest inhibition of trypsin and chymotrypsin activities i.e. $95.58 \%( \pm 0.4)$ and $55.91 \%( \pm 0.61)$ was observed at $50 \mu \mathrm{g} / \mathrm{ml}$ of SSTI (Fig. 2A). Purified SSTI was also assayed for its inhibitory activity against trypsin like protease enzyme isolated from gut of Helicoverpa armigera. Concentration dependent inhibition pattern was observed with Helicoverpa armigera Gut Protease (HGP). The concentration range of SSTI used for this study was $20-140 \mu \mathrm{g} / \mathrm{ml}$, lowest inhibition 


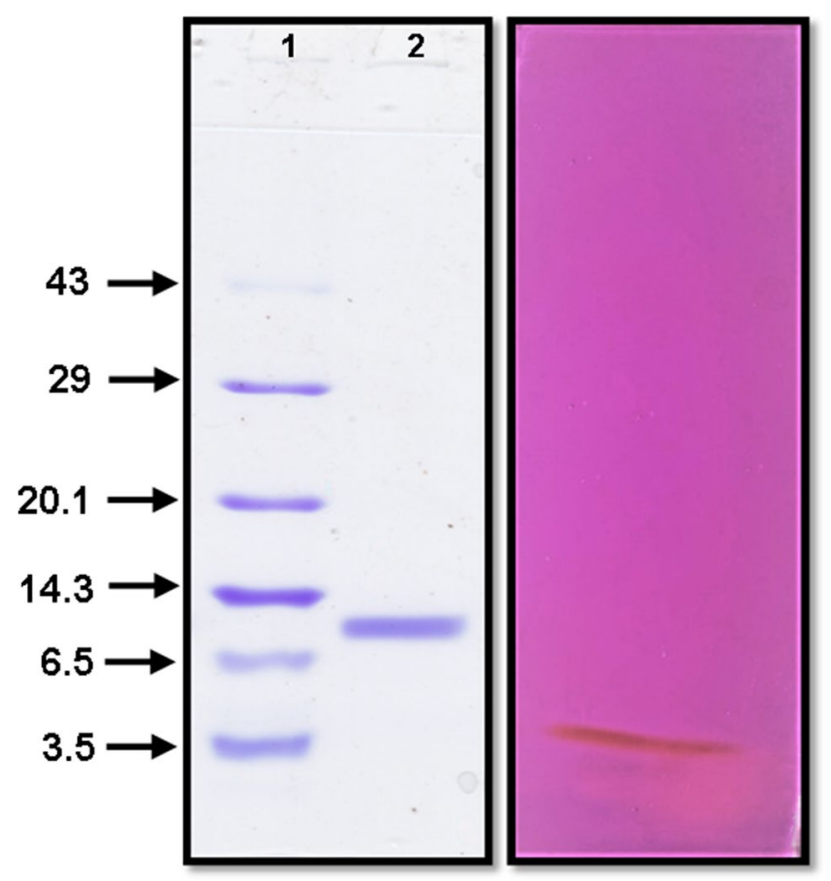

Figure 1. (A) SDS-PAGE profile (15\%), analyses of purified SSTI from, S. surattense seeds, stained with Coomassie Brilliant Blue. (1) Standard protein markers, (2) purified fraction after cation exchange resin; (B) PAS staining of purified SSTI, indicating its glycoprotein nature (12\% SDS-PAGE). Uncropped gel images are shown in Supplementary Figure S2A and B.
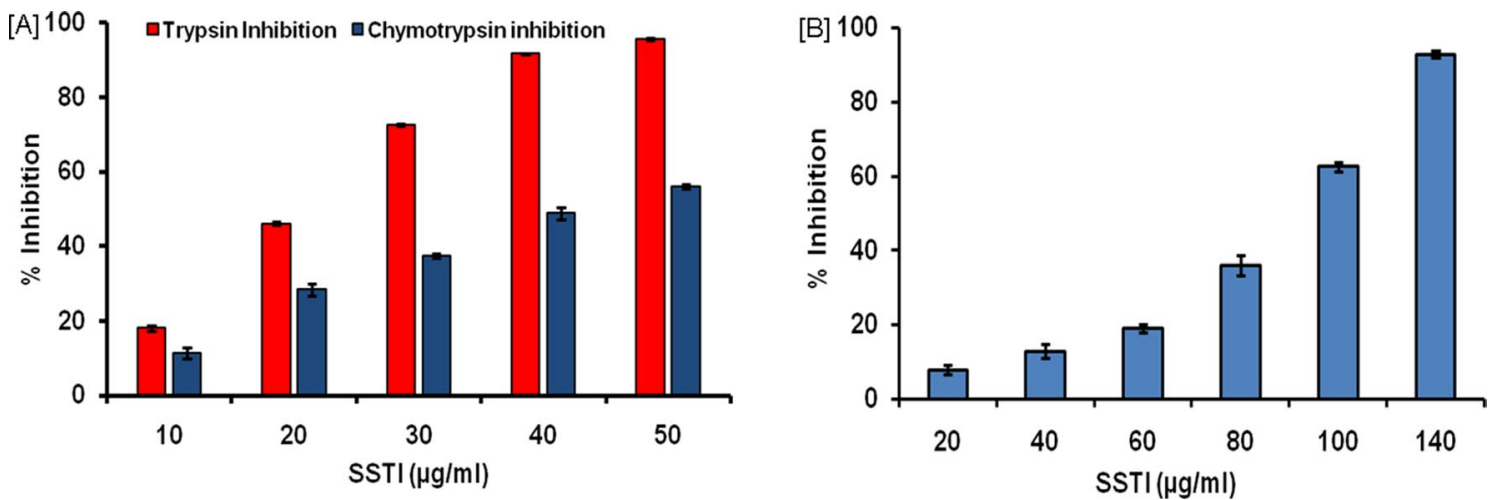

Figure 2. Concentration dependent inhibition of (A) Trypsin and Chymotrypsin (B) Gut proteases by Purified SSTI.

$(7.9 \% \pm 1.29)$ and highest inhibition of HGP $(92.9 \% \pm 1.05)$ was recorded at 20 and $140 \mu \mathrm{g} / \mathrm{ml}$ of SSTI (Fig. 2B). However, SSTI did not have inhibitory potential with other proteases (proteinase $\mathrm{k}$, subtilisin) even at the highest concentration used $(50 \mu \mathrm{g} / \mathrm{ml})$. A similar pattern of inhibition was reported for PI isolated from the seeds of Pithecellobium dumosum ${ }^{23}$. The PI from Cassia leiandra (CITI) has been reported to have inhibitory potential against various enzymes like bovine trypsin, chymotrypsin, papain and porcine $\alpha$-amylase ${ }^{30}$. Previously, the PIs are reported for inhibiting two or more proteases ${ }^{31}$.

SSTI is a member of Bowman-Birk protease inhibitor family. Trypsin/chymotrypsin inhibitor from S. surratence was subjected to peptide mass fingerprinting. LC/MS/MS analysis of trypsin digested SSTI led to the identification of a Bowman-Birk type protease inhibitor. Four unique peptides matched with a Bowman-Birk domain-containing protein from Glycine max (Accession no. C6SVG7) with a significant coverage of 46.15\%. Three other peptides matched with a Bowman-Birk type protease inhibitor from Phaseolus acutifolius (Accession no. P83311) with 41.25\% coverage (Table 2).

Bowman-Birk inhibitors from monocotyledons with molecular weight $\sim 16 \mathrm{kDa}$ have a double-headed structure of two separate functional inhibitory domains. The first reactive domain inhibits trypsin-like serine proteases 


\begin{tabular}{|c|c|c|c|c|c|}
\hline Sample & Coverage $\%$ & Accession ID & Protein name & Observed peptide sequence & MW (da) \\
\hline SSTI & 46.15 & C6SVG7 & Bowman-Birk domain-containing protein OS $=$ Glycine $\max$ & $\begin{array}{l}\text { MELSMKVLVKVASLLFLLEF } \\
\text { TATVVDARFDPSSFITQFLPNA } \\
\text { EANNYYVKSTTKACCNSCPCT } \\
\text { KSIPPQCRCSDIGETCHSACK } \\
\text { TCICTRSIPPQCHCSDITNFCY } \\
\text { EPCNSSETEAH }\end{array}$ & 12.9 \\
\hline SSTI & 41.25 & P83311 & $\begin{array}{l}\text { Bowman-Birk type proteinase inhibitor OS= Phaseolus } \\
\text { acutifolius }\end{array}$ & $\begin{array}{l}\text { SGHHHHDSSDEPSESSKACCD } \\
\text { HCACTKSIPPQCRCALRLNCN } \\
\text { HCRSCICTFSIPAQCVCTDTND } \\
\text { FCYEPCKSGHDDDDSG }\end{array}$ & 8.7 \\
\hline
\end{tabular}

Table 2. Mass spectroscopic profiles of SSTI protein from Solanum surattence. Peptides that matched with specific region of earlier kwon Bowman-Birk type protease inhibitors are highlighted in different colors and bold.
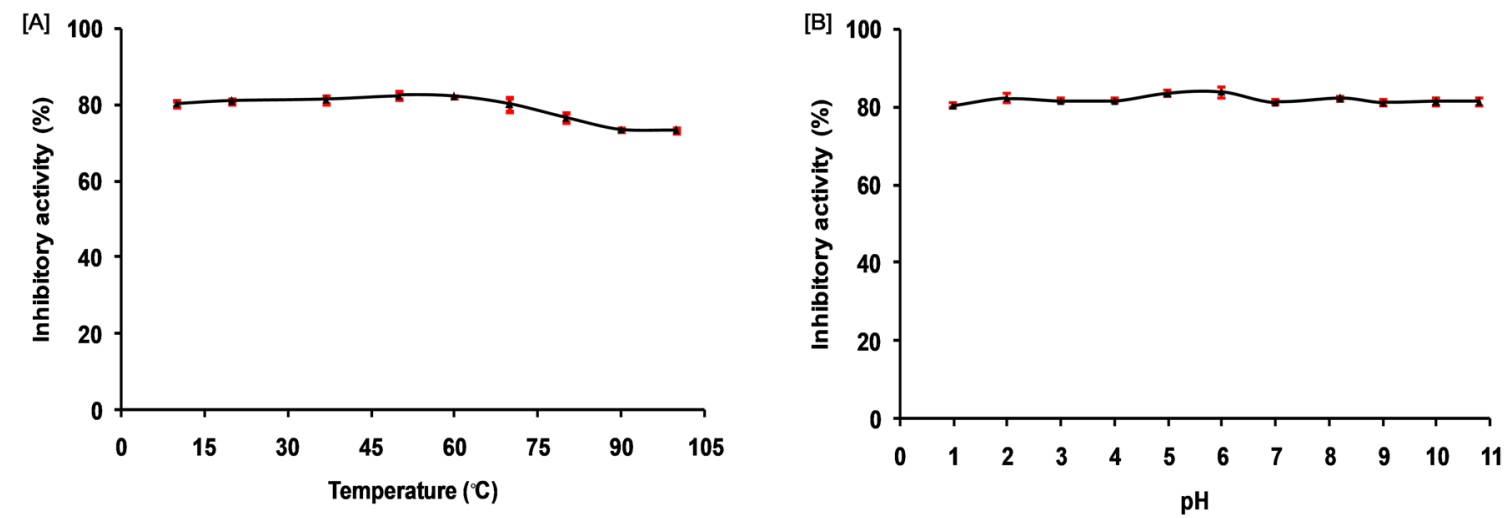

Figure 3. Stability of purified trypsin inhibitor (A) Temperature stability of purified SSTI incubation for $30 \mathrm{~min}$ at the indicated temperature, (B) $\mathrm{pH}$ stability of purified SSTI incubation at different $\mathrm{pH}$ for $30 \mathrm{~min}$ at $37^{\circ} \mathrm{C}$; The residual trypsin inhibitory activity was measured using BApNA as a substrate. In statistical analysis, oneway ANOVA was performed, followed by Tukey's post hoc test. Statistical data are significant at $P<0.001$.

mainly a positively charged residue (Arg or Lys) and the second domain with a large hydrophobic residue (Trp, Leu, Phe or Tyr) inhibits chymotrypsin-like serine proteases and a short hydrophobic residue (Val or Ile) inhibits elastase $^{32,33}$. The peptide sequence of SSTI showed six amino acid residues (S-I-P-P-Q-C) which are observed to be conserved among many members of a Bowman-Birk type inhibitors ${ }^{34}$. This consensus sequence homology revealed that SSTI is a new member of the Bowman-Birk type protease inhibitor family with a unique cysteine framework.

SSTI remains stable at a wide range of $\mathrm{pH}$ and temperatures. The thermal stability study showed that SSTI remained stable between 10 and $70{ }^{\circ} \mathrm{C}$ and experienced moderate loss in trypsin-inhibition activity at higher temperatures, at $100^{\circ} \mathrm{C}$ SSTI showed nearly $11 \%$ loss in trypsin inhibition capability (Fig. 3A). SSTI maintained substantial inhibitory potential against target trypsin enzyme up to $100^{\circ} \mathrm{C}$. It is observed by earlier researchers that protease inhibitors isolated from seeds are quite thermostable up to $100{ }^{\circ} \mathrm{C}$ for example; inhibitors isolated from seeds of Phaseolus aureus Roxb. (Mung bean), Pithecellobium dumosum and Rhynchosia sublobata (Schumach.) $)^{23,35,36}$. In pH stability study, we observed that SSTI has no remarkable loss in trypsin inhibition between the $\mathrm{pH}$ range of 1.0-10.8 and it retained its functional strength at extreme $\mathrm{pH}$ conditions (acidic as well as alkaline conditions) (Fig. 3B). This type of broad pH stability is reported in Bowman-Birk family trypsin inhibitors isolated from seeds of Canavalia lineate seeds, Glycine soja (wild Soja) and Phaseolus aureus Roxb. (Mung bean) ${ }^{36-38}$ and kunitz-type inhibitors from Peltophorum dubium seeds ${ }^{27}$. Generally, the stability of a BBI type trypsin inhibitors towards physical (temperature, $\mathrm{pH}$ ) and chemical (reducing agents) denaturants is associated with the presence of several disulfide bonds ${ }^{33,39}$.

CD spectroscopy. CD spectra have been used to analyze the secondary structure of SSTI at different $\mathrm{pH}$ and temperatures. Far-UV CD spectra of SSTI are presented in Fig. 4; it exhibited an intense negative peak at $225-240 \mathrm{~nm}$ and no positive ellipticity. According to this study, SSTI is composed of $23 \% \beta$-sheets and $6.03 \%$ a 
[A]

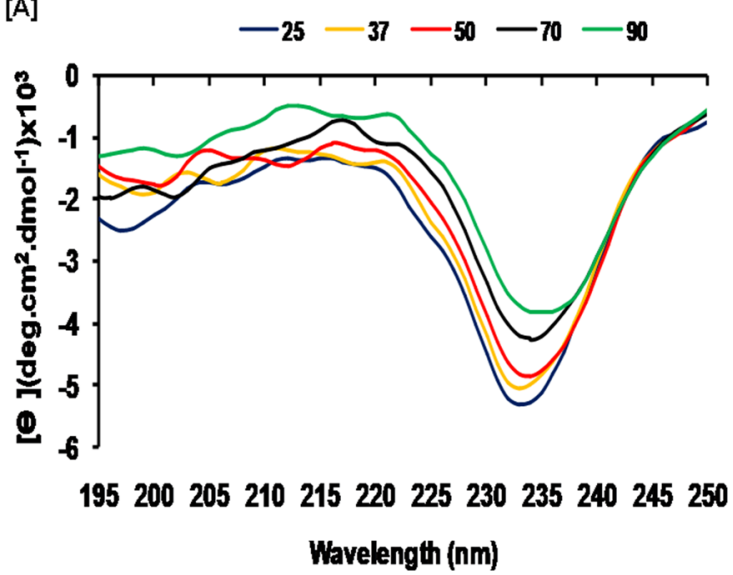

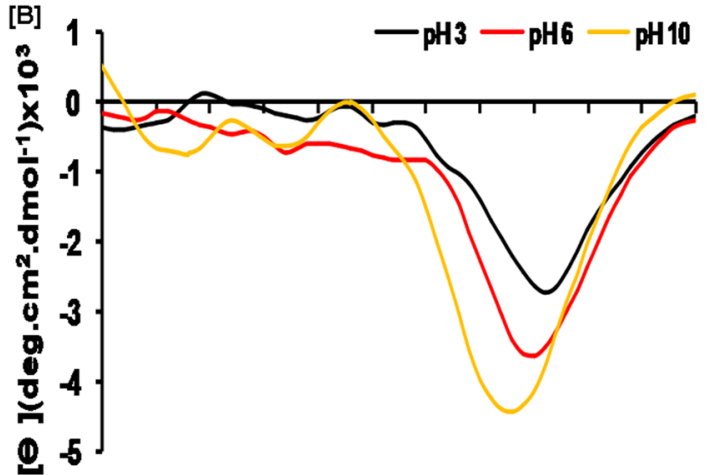

195200205210215220225230235240245250 Wavelength $(\mathrm{nm})$

Figure 4. CD studies of SSTI (A) Far UV CD spectra (195-250 nm) as function of different temperature incubate for $30 \mathrm{~min}$ and (B) Different $\mathrm{pH}$ incubate for $30 \mathrm{~min}$.

helix. The conformational stability studied by CD spectra analysis demonstrated the thermal and pH stability of SSTI structure. Increasing temperature and extreme $\mathrm{pH}$ resulted no progressive loss of the conformational pattern of SSTI and retain the structural stability (Fig. 4A,B). These observations are in supportive to with our observations about SSTIs stability at higher temperatures and wide range of $\mathrm{pH}$. Previously, significant structural stability in broad $\mathrm{pH}$ and high temperatures is reported for other Bowman-Birk protease inhibitor ${ }^{34,39}$. Circular dichromism study confirmed that the protein contained high $\beta$-sheet structures; a similar pattern of secondary structural elements was reported for PI isolated from Rhynchosia sublobata (Schumach.) Meikle seeds ${ }^{35,39}$.

SSTI shows noncompetitive (mixed) type of trypsin inhibition. To understand the inhibition mechanism of SSTI, data generated by the kinetic study was analyzed through Michaelis-Menten kinetics, Lineweavere Burk plot and Dixon plots by following a single substrate-single inhibitor approach. According to Michaelis-Menten plot, the inclusion of SSTI affected the velocity of trypsin catalyzed proteolysis (Fig. 5A). We have observed that $\mathrm{Km}$ and Vmax in absence of inhibitor were found to be $1.6 \mathrm{mM}$ and $200 \mathrm{U}(\mu \mathrm{M} / \mathrm{min} / \mathrm{ml})$ respectively. However, in presence of SSTI, the Km and Vmax were observed to be $1.81 \mathrm{mM}$ and $90.9 \mathrm{U}$ respectively (Fig. 5B). These findings are suggestive of noncompetitive (mixed) type inhibition by SSTI. The inhibition constant (Ki) for purified SSTI obtained from the Dixon plot, was $2 \mu \mathrm{g} / \mathrm{ml}$ equivalent to $16.6 \times 10^{-8} \mathrm{M}$ (calculated based on the molecular weight of PI) (Fig. 5C). A similar type of inhibition was reported earlier with PI obtained from seeds of Tamarindus indica and Entada scandens with Ki values of $1.7 \times 10^{-9} \mathrm{M}$ and $4.9 \times 10^{-9} \mathrm{M}$, respectively ${ }^{40,41}$.

Interactions of SSTI with trypsin as evaluated by isothermal titration calorimetry. Isothermal titration calorimetry is a powerful and very sensitive technique based on the simple measurement of heat changes ( $q$ ) as a consequence of the biomolecular interaction. When a molecule goes from free-state to bound state it is invariably associated with either redistribution or formation of non-covalent bonds which results in heat changes and ITC makes note of these changes in terms of differential power needed to maintain the zero temperature difference between the sample and reference cell. ITC data analysis revealed that the isolated inhibitor is tightly bound to trypsin with $\mathrm{K}_{\mathrm{d}}$ value of $2.28 \mu \mathrm{M}$ (Fig. 5D). Binding actions are characterized by a largely favorable enthalpy with $\Delta \mathrm{H}$ value of $-80 \mathrm{kcal} / \mathrm{mol}$ and entropy change $(-\mathrm{T} \Delta \mathrm{S})$ value of $72 \mathrm{kcal} / \mathrm{mol}$. Using this technique, we have plotted a signature plot for the same which revealed the interactions having significant hydrogen bonding and van der Waals interactions.

\section{Methods}

The study on plant material including the collection of seeds had complied with relevant institutional, national and international guidelines and legislation.

Plant Materials. The plant materials for the present study were collected from Kagal MIDC, Kolhapur, Maharashtra, India ( $\left.16^{\circ} 37^{\prime} 08.2^{\prime \prime} \mathrm{N}, 74^{\circ} 21^{\prime} 12.4^{\prime \prime} \mathrm{E}\right)$. The specimens were then identified by Dr. Manoj M. Lekhak, Assistant Professor, Department of Botany, Shivaji University, Kolhapur, Maharashtra, India and the voucher specimens (001) deposited in the Herbarium of Department of Botany, Shivaji University, Kolhapur, Maharashtra, India. The plant materials were collected with the permission and guidance by the local authority at Kagal MIDC, Kolhapur, Maharashtra, India. An official letter of permission was submitted and approved by the authorities prior to sample collection. The seeds were used for experimentation after washing and cleaning and kept in clean, dried environment at room temperature. 

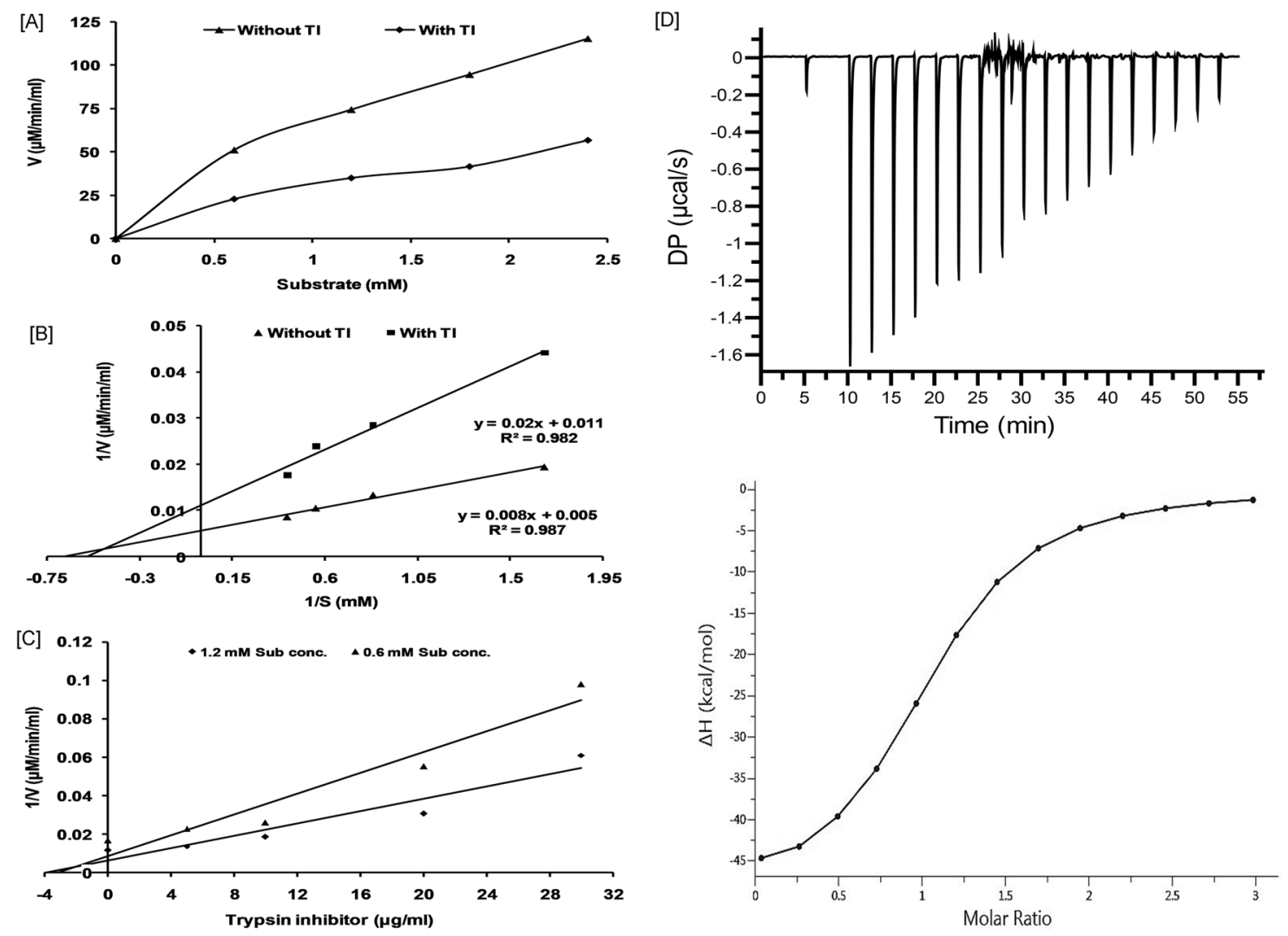

Figure 5. Kinetic analysis of purified SSTI. Noncompetitive (mixed) type of inhibition of bovine trypsin (A) Michaelis-Menten kinetics of bovine trypsin in presence and in absence of SSTI. (B) Lineweaver-Burk plot of $1 /[\mathrm{V}]$ versus $1 /[\mathrm{S}]$ of bovine trypsin in presence and in absence of SSTI. (C) Dixon's plot of $1 /[\mathrm{V}]$ versus [I] of bovine trypsin in presence of different concentrations of SSTI at two different concentrations of BApNA. The Ki value for SSTI was $16.6 \times 10^{-8} \mathrm{M}$. (D) Interaction by Isothermal titration of purified SSTI with bovine trypsin.

Isolation and purification of trypsin inhibitor (SSTI) protein from the seeds of S. surattense. Ten gram fine powder of dried seeds of S. surattense (Syn. S. virginianum) was taken to prepare a crude extract of trypsin inhibitor. The extraction of proteins was performed as per the method described by Kasar et al. ${ }^{42}$ with slight modifications. The crude extract was centrifuged at $4712 \times g$ for $20 \mathrm{~min}$ at $4{ }^{\circ} \mathrm{C}$ and the resultant supernatant was used for ammonium sulphate precipitation $(80 \%)$. The precipitated pellets thus obtained were used for dialysis followed by lyophilization. Further, concentrated dialyzed proteins were subjected to CM-Cellulose pre-packed column $(20 \mathrm{~cm} \times 3 \mathrm{~cm})$ pre-equilibrated with citrate buffer $(\mathrm{pH} 5.3,0.02 \mathrm{M})$ for ion exchange chromatography. The fractions showing the highest trypsin inhibition were pooled and concentrated using Amicon Ultra-15 centrifugal filter units (Sigma Aldrich, St. Louis, MO, USA). Total protein content at each step of purification was determined as per the method described by Lowry et al. ${ }^{43}$.

Studies on protease inhibitory activity of SSTI. Protease inhibitory potential of SSTI was evaluated on different proteases like Bovine pancreatic trypsin, Chymotrypsin, Proteinase K, Subtilisin and H. armigera gut protease (gut homogenate was used as protease source).

Trypsin inhibitory activity assay was performed using bovine pancreatic trypsin and its synthetic substrate Benzoyl-Arginyl- $p$-Nitro-Anilide (BApNA) by a following method described by Erlanger et al. ${ }^{44}$ In this, different concentrations ( 5 to $50 \mu \mathrm{g} / \mathrm{ml}$ ) of purified S. Surattense trypsin inhibitor (SSTI) were added to $30 \mu \mathrm{l}$ of trypsin $(300 \mu \mathrm{g} / \mathrm{ml})$ followed by addition of $0.1 \mathrm{M}$ Tris- $\mathrm{HCl}$ buffer $\left(\mathrm{pH} 8.0\right.$ containing $20 \mathrm{mM} \mathrm{CaCl}_{2}$ ) to achieve the volume of enzyme and its inhibitor mixture to $300 \mu \mathrm{l}$ and incubated at $37^{\circ} \mathrm{C}$ for $15 \mathrm{~min}$. Then, $500 \mu \mathrm{BApNA}$ $(1.25 \mathrm{mM})$ was added in pre-warmed mixture and incubated at $37^{\circ} \mathrm{C}$ for $15 \mathrm{~min}$. After incubation, reaction was stopped by adding $200 \mu \mathrm{l}$ of $30 \%(\mathrm{v} / \mathrm{v})$ glacial acetic acid and liberated p-nitroaniline was monitored at $410 \mathrm{~nm}$. One Trypsin inhibitor unit (TIU) was defined as amount of inhibitor needed to decrease the absorbance by 0.01 units at $410 \mathrm{~nm}$ under the trypsin inhibition assay ${ }^{45}$.

Besides trypsin inhibition, Chymotrypsin, Proteinase K, Subtilisin inhibitory activity of SSTI was also assayed using Caseinolytic approaches as reported by Marathe et al. ${ }^{22}$ with slight modifications. Protease inhibitor $50 \mu \mathrm{g} /$ $\mathrm{ml}$ was preincubated with different proteases at $37^{\circ} \mathrm{C}$ for $15 \mathrm{~min}$. After preincubation, $500 \mu \mathrm{l}$ of $0.1 \%$ casein was added and incubated at $37^{\circ} \mathrm{C}$ for $15 \mathrm{~min}$. Then, the reaction was terminated by adding $300 \mu \mathrm{l}$ of $10 \%$ trichloroacetic acid (TCA) solution. The samples were centrifuged and the supernatant was measured at $280 \mathrm{~nm}$ using a UV-Visible spectrophotometer (Shimadzu, Japan). 
For extraction of crude protease, the mid gut tissues were dissected carefully from the fourth or fifth instar larvae of $H$. armigera as described by Giri et al. ${ }^{46}$ The excised midgut tissue samples were collected and homogenized in chilled $0.1 \mathrm{M}$ Tris- $\mathrm{HCl}$ buffer $(\mathrm{pH} 8.8)$. The suspension was centrifuged at $4{ }^{\circ} \mathrm{C}$ for $20 \mathrm{~min}$ at $4712 \times g$. The supernatant was collected and assayed for protease enzymic activity as described earlier ${ }^{45}$.

Determination of molecular weight of SSTI using SDS-PAGE and gel permeation chromatography. The molecular mass of isolated SSTI was determined on polyacrylamide gel (15\%) under reducing conditions as described by Laemmli ${ }^{47}$. Trypsin inhibitory active fractions were separated by using SDS-PAGE and visualized by staining with Coomassie Brilliant Blue (CBB-R-250) for $60 \mathrm{~min}$ followed by distaining with methanol:acetic acid:water (30:20:50). The molecular weight of purified SSTI protein was calculated by comparing its relative position with molecular weight markers. Further, a molecular weight of purified SSTI was also confirmed by using size exclusion chromatography on a pre-equilibrated Sephadex G-50, Tris- $\mathrm{HCl}(20 \mathrm{mM}, \mathrm{pH}$ $7.5)$ column $(105 \mathrm{~cm} \times 1.8 \mathrm{~cm})$.

Determination of carbohydrate content and glycoprotein staining analysis. Total carbohydrate content present with purified SSTI was estimated by phenol sulphuric acid method by using glucose as a standard ${ }^{48}$. Phenol-sulphuric-acid-positive carbohydrates were expressed as a percentage of glucose equivalent as determined from a standard calibration curve using $0.1 \mathrm{mg} / \mathrm{ml}$ stock solution of glucose. Glycoprotein nature of purified SSTI was determined by Periodic Acid Schiff (PAS) staining as described by Kasar et al. ${ }^{43}$.

Mass spectrometry analysis. $100 \mu \mathrm{g}$ equivalent protein was subjected to reduction, alkylation followed by digestion for $16-20 \mathrm{~h}$ at $37^{\circ} \mathrm{C}$ using sequencing-grade modified trypsin: proteins ( $\left.1 \mu \mathrm{g}: 20 \mathrm{ug} \mathrm{w} / \mathrm{w}\right)$. The samples were desalted and subjected to LC-MS/MS analysis. The peptides were eluted by a 3-95\% gradient of buffer $\mathrm{B}$ (aqueous $80 \%$ acetonitrile in $0.1 \%$ formic acid) at a flow rate of $300 \mathrm{nl} / \mathrm{min}$ for about $60 \mathrm{~min}$ on a $25-\mathrm{cm}$ analytical C18 column $(\mathrm{C} 18,3 \mu \mathrm{m}, 100 \AA$ ) . The peptides were ionized by nano-electrospray and subsequent tandem mass spectrometry (MS/MS) on a Q-Exactive Plus was performed and analyzed using a mass spectrometer with the collision-induced dissociation mode with the electrospray voltage was $2.3 \mathrm{kV}$. Analysis on the orbitrap was performed with full scan MS spectra with a resolution of 70,000 from m/z 350 to 1800 . The MS/MS data were analyzed by Proteome Discoverer (version 2.3, Thermo Fisher Scientific, Waltham, MA, United States) using the Self curated data base of the protease inhibitors (The Uniprot data base). Proteins with FDR $>0.01$ and $p$ value $>0.05$ were only used for analysis ${ }^{49}$.

Thermo-stability and $\mathrm{pH}$ tolerance. The impact of $\mathrm{pH}$ and temperature on the inhibitory activity of SSTI was evaluated according to Dias et al. ${ }^{30}$ To study the thermal stability of SSTI, it was incubated at varying temperatures ranging from 10 to $100{ }^{\circ} \mathrm{C}\left( \pm 1^{\circ} \mathrm{C}\right)$ for $30 \mathrm{~min}$. After incubation at various temperatures aliquots were cooled and activity was measured against the bovine trypsin. Similarly, to check pH stability of SSTI, aliquots of SSTI were incubated with different $\mathrm{pH}$ buffers $(0.05 \mathrm{M})$, namely $\mathrm{KCl}-\mathrm{HCl}$ buffer $(\mathrm{pH} 1-3)$, citrate buffer ( $\mathrm{pH} 4-6)$, phosphate buffer ( $\mathrm{pH} 7$ ), Tris-Cl buffer ( $\mathrm{pH}$ 8-9) and Glycine-NaOH buffer (pH10-11) for 30 min at $37^{\circ} \mathrm{C}$ and activity was measured against the bovine trypsin.

Circular dichroism (CD) spectroscopy. All far-UV CD spectra (195-250) were obtained under nitrogen atmosphere at $25^{\circ} \mathrm{C}$ and recorded on a JASCO J-715 (Jasco Inc., Easton, MD, USA) spectropolarimeter using solutions of a protein concentration $1 \mathrm{mg} / \mathrm{ml}$ in the quartz cuvette with a 1-mm optical path. All spectra were generated by taking an average of three scans and were corrected for the respective blanks. Results are expressed as molar ellipticity, $[\Theta]\left(\mathrm{deg} \mathrm{cm}^{2} / \mathrm{dmol}\right)$, based on a mean amino acid residue weight $(\mathrm{MRW})^{50}$.

Analysis of kinetic behavior of SSTI with trypsin. The kinetic behavior of SSTI during its interaction with trypsin was studied with different concentrations of the inhibitor [I] and substrate [S]. A Lineweaver-Burk graph was plotted and analyzed to determine the nature of inhibition. For this, $30 \mu \mathrm{l}$ of trypsin $(0.3 \mathrm{mg} / \mathrm{ml})$ was incubated with different concentrations of substrate ranging from 0.6 to $2.4 \mathrm{mM}$ BApNA (at an interval of $0.6 \mathrm{mM}$ ). The reaction was stopped by the addition of $200 \mu \mathrm{l}$ of $30 \%(\mathrm{v} / \mathrm{v})$ acetic acid. The liberated compound p-nitroaniline was measured at $410 \mathrm{~nm}$. The $\mathrm{Km}$ and Vmax values of trypsin were determined by a double reciprocal plot of substrate concentration v/s velocity in the presence and absence of SSTI. The Ki value was determined through Dixon's plot by assaying trypsin with various concentrations of SSTI at two substrate concentrations ( 0.6 and $1.25 \mathrm{mM})$ under standard assay conditions $\mathrm{s}^{51}$.

Isothermal titration calorimetry study of SSTI. A MicroCal PEAQ-ITC instrument (Malvern Panalytical Ltd., U.K.) was used to determine the thermodynamic properties of a chemical or physical equilibria resulting from the titration of $0.1 \mathrm{mM}$ SSTI with $1 \mathrm{mM}$ bovine trypsin in titration buffer $(10 \mathrm{mM}$ Tris at $\mathrm{pH}$ 7.8). Nineteen injections of $2 \mu \mathrm{l} \mathrm{SSTI}$ injected sequentially into a titration cell at $37^{\circ} \mathrm{C}$ containing $300 \mu \mathrm{l}$ trypsin. Each injection was delivered after every $200 \mathrm{~s}$. The MicroCal PEAQ-ITC Analysis Software was used to extract the data file using the "One Binding Site" fitting model. Further analysis of kcal mol${ }^{-1}$ of injection of ligand vs molar ratio graph enabled calculation of affinity constants $\left(\mathrm{K}_{\mathrm{d}}\right)$, binding enthalpy changes $(\Delta \mathrm{H})$ and binding stoichiometry $(\mathrm{n})$ by fitting the integrated titration peaks. 
Data analysis. Data from the protease inhibition assay, SSTI stability study were subjected to statistical analysis, one-way ANOVA followed by Tukey's post hoc test. The $p$ value was considered to be greater than the $\alpha$-value (level of significance 0.05 , i.e. $p<0.05$ ).

\section{Conclusion}

In present investigation a functional glycoprotein SSTI was isolated and purified from the seeds of S. surattense, a medicinally important member of the family Solanaceae. SSTI is identified as a Bowman-Birk type protease inhibitor family with a unique consensus sequence. It was temperature-pH tolerant protein and has inhibitory efficacy with trypsin and chymotrypsin. Circular dichroism confirmed that the protein contained high $\beta$-sheet structures. The monomeric low molecular weight SSTI was revealed to be a noncompetitive (mixed) type inhibitor of trypsin. In future, a detailed molecular interaction, protein engineering and structural analysis study will be helpful to throw a light on its actual mechanism of inhibition.

Received: 20 July 2020; Accepted: 31 March 2021

Published online: 21 April 2021

\section{References}

1. Bowles, D. J. Defense-related proteins in higher plants. Annu. Rev. Biochem. 59, 873-907 (1990).

2. Neuhaus, J. M. \& Rogers, J. C. Sorting of proteins to vacuoles in plant cells. Plant Mol. Biol. 38, 127-144 (1998).

3. Brahim S. E, Usha K. \& Singh B. Pathogenesis related (PR) proteins in plant defense mechanism in Communicating current research and technological advances (Ed. Méndez Vilas A.) 1043-1054 (Formatex Research Center). (2011).

4. Zhu-Salzman, K. \& Zeng, R. Insect response to plant defensive protease inhibitors. Annu. Rev. Entomol. 60, 233-252 (2014).

5. Meenu Krishnan, V. G. \& Murugan, K. Solanum protease inhibitors and their therapeutic potentialities: A review. Int. J. Pharm. Pharm. Sci. 8, 14-21 (2016).

6. Vajravijayan, S., Pletnev, S., Pletnev, V. Z., Nandhagopal, N. \& Gunasekaran, K. Crystal structure of a novel Kunitz type inhibitor, alocasin with anti-Aedes aegypti activity targeting midgut proteases. Pest Manag. Sci. https://doi.org/10.1002/ps.5063 (2018).

7. Osman, M. A., Reid, P. M. \& Weber, C. W. Thermal inactivation of tepary bean (Phaseolus acutifolius), soybean and lima bean protease inhibitors: Effect of acidic and basic pH. Food Chem. 78, 419-423 (2002).

8. Zavala, J. A., Patankar, A. G., Gase, K., Hui, D. \& Baldwin, I. T. Manipulation of endogenous trypsin proteinase inhibitor production in Nicotiana attenuata demonstrates their function as antiherbivore defenses. Plant Physiol. 134, 1181-1190 (2004).

9. Padul, M. V., Tak, R. D. \& Kachole, M. S. Protease inhibitor (PI) mediated defense in leaves and flowers of pigeonpea (protease inhibitor mediated defense in pigeonpea). Plant Physiol. Biochem. 52, 77-82 (2012).

10. Stevens, J. A. et al. The impact of ingested potato type II inhibitors on the production of the major serine proteases in the gut of Helicoverpa armigera. Insect Biochem. Mol. Biol. 43, 197-208 (2013).

11. Gatehouse, A. M. R. \& Gatehouse, J. A. Identifying proteins with insecticidal activity: Use of encoding genes to produce insectresistant transgenic crops. Pestic. Sci. 52, 165-175 (1998).

12. Carlini, C. R. \& Grossi-de-Sá, M. F. Plant toxic proteins with insecticidal properties. A review on their potentialities as bioinsecticides. Toxicon 40, 1515-1539 (2002).

13. Shamsi, T. N., Parveen, R. \& Fatima, S. Characterization, biomedical and agricultural applications of protease inhibitors: A review. Int. J. Biol. Macromol. 91, 1120-1133 (2016).

14. Pearce, G., Sy, L., Russel, C., Ryan, C. A. \& Hass, G. M. Isolation and characterization from potato tubers of two polypeptide inhibitors of serine proteinases. Arch. Biochem. Biophys. 213, 456-465 (1982).

15. Speransky, A. S. et al. Kunitz-type protease inhibitors group B from Solanum palustre. Biotechnol. J. 2, 1417-1424 (2007).

16. Hartl, M., Giri, A. P., Kaur, H. \& Baldwin, I. T. Serine protease inhibitors specifically defend Solanum nigrum against generalist herbivores but do not influence plant growth and development. Plant Cell 12, 4158-4175 (2010).

17. Sheeba, E. Antibacterial Activity of Solanum surattense Burm. F. Kathmandu Univ. J. Sci. Eng. Technol. 6, 1-4 (1970).

18. Ali, R., Sedigheh, Z., Soroush, S., Nastaran, K. \& Navid Dinparas, D. In vitro and in vivo anti-malarial activity of Boerhavia elegans and Solanum surattense. Malar. J. 9, 1-8 (2006).

19. Thirumalai, T., David, E., Therasa, S. V. \& Elumalai, E. K. Effect of Solanum surattense seed on the oxidative potential of cauda epididymal spermatozoa. Asian Pac. J. Trop. Biomed. 2, 21-23 (2012).

20. Ee, K. Y., Zhao, J., Rehman, A. \& Agboola, S. O. Purification and characterization of a Kunitz-type trypsin inhibitor from Acacia victoriae Bentham seeds. J. Agric. Food Chem. 57, 7022-7029 (2009).

21. Abd El-latif, A. O. In vivo and in vitro inhibition of Spodoptera littoralis gut-serine protease by protease inhibitors isolated from maize and sorghum seeds. Pestic. Biochem. Phys. 116, 40-48 (2014).

22. Marathe, K., Kasar, S., Chaudhari, A. \& Maheshwari, V. Purification and characterization of a novel heterodimer protease inhibitor from Streptomyces spp. VL J2 with potential biopesticidal activity against H. armigera. Process Biochem. 51, 1650-1663 (2016).

23. Oliveira, A. S. et al. Purification and characterization of a trypsin-papin inhibitor from Pithecelobium dumosum seeds and it in vitro effects towards digestive enzymes from insect pests. Plant Physiol. Biochem. 45, 858-865 (2007).

24. Bijina, B. et al. Protease inhibitor from Moringa oleifera leaves: isolation, purification and characterization. Process Biochem. 46, 2291-2300 (2011).

25. Shah, K. R., Patel, D. K., Pappachan, A., Prabha, C. R. \& Singh, D. D. Characterization of a Kunitz-type serine protease inhibitor from Solanum tuberosum having lectin activity. Int. J. Biol. Macromol. 83, 259-269 (2016).

26. Maria do Socorro, M. C. et al. Characterization of a Kunitz trypsin inhibitor with one disulfide bridge purified from Swartzia pickellii. Biochem. Biophys. Res. Commun. 291, 635-639 (2002).

27. Macedo, M. L. R. et al. A trypsin inhibitor from Peltophorum dubium seeds active against pest proteases and its effect on the survival of Anagasta kuehniella (Lepidoptera: Pyralidae). Biochim. Biophys. Acta Gen. Subj. 1621, 170-182 (2003).

28. Paiva, P. M. G. et al. Isolation of trypsin inhibitor from Echinodorus paniculatus seeds by affinity chromatography on immobilized Cratylia mollis isolectins. Bioresour. Technol. 88, 75-79 (2003).

29. Ee, K. Y., Zhao, J., Rehman, A. \& Agboola, S. Glycosylation, amino acid analysis and kinetic properties of a major Kunitz-type trypsin inhibitor from Acacia victoriae Bentham seeds. Food Chem. 129, 1224-1227 (2011).

30. Dias, L. P. et al. A trypsin inhibitor purified from Cassia leiandra seeds has insecticidal activity against Aedes aegypti. Process Biochem. 57, 228-238 (2017).

31. Cruz, A. C. et al. Bioinsecticidal activity of a novel Kunitz trypsin inhibitor from Catanduva (Piptadenia moniliformis) seeds. Plant Physiol. Biochem. 70, 61-68 (2013).

32. Gu, C., Song, X., Zhao, L., Pan, S. \& Qin, G. Purification and characterization of Bowman-Birk trypsin inhibitor from soybean. J. Food Nutr. Res. 2, 546-550 (2014). 
33. Gitlin-domagalska, A., Maciejewska, A. \& Debowski, D. Bowman-Birk inhibitors: Insights into family of multifunctional proteins and peptides with potential therapeutical applications. Pharmaceuticals 13, 421 (2020).

34. Dantzger, M. et al. Phytochemistry Bowman-Birk proteinase inhibitor from Clitoria fairchildiana seeds: Isolation, biochemical properties and insecticidal potential. Phytochem https://doi.org/10.1016/j.Phytochem.2015.08.013 (2015).

35. Mohanraj, S. S., Tetali, S. D., Mallikarjuna, N., Dutta-Gupta, A. \& Padmasree, K. Biochemical properties of a bacterially-expressed Bowman-Birk inhibitor from Rhynchosia sublobata (Schumach.) Meikle seeds and its activity against gut proteases of Achaea janata. Phytochemistry 151, 78-90 (2018).

36. Haq, S. K., Atif, S. M. \& Khan, R. H. Biochemical characterization, stability studies and N-terminal sequence of a bi-functional inhibitor from Phaseolus aureus Roxb. (Mung bean). Biochimie 87, 1127-1136 (2005).

37. Terada, S., Fujimura, S., Kino, S. \& Kimoto, E. Purification and Characterization of three proteinase inhibitors from Canavalia lineata seeds. Biosci. Biotechnol. Biochem. 58, 371-375 (1994).

38. Deshimaru, M., Hanamoto, R., Kusano, C., Yoshimi, S. \& Terada, S. Purification and characterization of proteinase inhibitors from Wild Soja (Glycine soja) Seeds. Biosci. Biotechnol. Biochem. 66, 1897-1903 (2002).

39. Mohanraj, S. S. et al. Purification and characterization of Bowman-Birk and Kunitz isoinhibitors from the seeds of Rhynchosia sublobata (Schumach.) Meikle, a wild relative of pigeonpea. Phytochemistry 159, 159-171 (2019).

40. Araujo, C. L. et al. In vivo bioinsecticidal activity toward Ceratitis capitata (Fruit Fly) and Callosobruchus maculatus (Cowpea Weevil) and in vitro bioinsecticidal activity toward different orders of insect pests of a trypsin inhibitor purified from tamarind tree (Tamarindus indica) seeds. J. Agric. Food Chem. 53, 4381-4387 (2005).

41. Lingaraju, M. H. \& Gowda, L. R. A Kunitz trypsin inhibitor of Entada scandens seeds: Another member with single disulfide bridge. Biochim. Biophys. Acta Proteins Proteomics 1784, 850-855 (2008).

42. Kasar, S. S. et al. A glycoprotein $\alpha$-amylase inhibitor from Withania somnifera differentially inhibits various $\alpha$-amylases and affects the growth and development of Tribolium castaneum. Pest Manag. Sci. 73, 1382-1390 (2017).

43. Lowry, O. H., Rosebrough, N. J., Farr, A. L. \& Randall, R. J. Protein measurement with the Folin phenol reagent. J. Biol. Chem. 193, 265-275 (1951).

44. Erlanger, B. F., Kokowsky, N. \& Cohen, W. The preparation and properties of two new chromogenic substrates of trypsin. Arch. Biochem. Biophys. 95, 271-278 (1961).

45. Gomes, C. E. et al. Effect of trypsin inhibitor from Crotalaria pallida seeds on Callosobruchus maculatus (cowpea weevil) and Ceratitis capitata (fruit fly). Plant Physiol. Biochem. 43, 1095-1102 (2005).

46. Giri, A. P. et al. Chickpea defensive proteinase inhibitors can be inactivated by Podborer Gut proteinases. Plant Physiol. 116, 393-401 (1998).

47. Laemmli, U. K. Cleavage of structural proteins during the assembly of the head of bacteriophage T4. Nature 227, 680-685 (1970).

48. Dubois, M., Gilles, K. A., Hamilton, J. K., Rebers, P. A. \& Smith, F. Colorimetric method for determination of sugars and related substances. Anal. Chem. 28, 350-356 (1956).

49. Maras, J. S. et al. Multi-Omics integration analysis of respiratory specimen characterizes baseline molecular determinants associated with COVID-19 diagnosis. medRxiv https://doi.org/10.1101/2020.07.06.20147082 (2020).

50. Haq, S. K. \& Khan, R. H. Characterization of a proteinase inhibitor from Cajanus cajan (L.). J. Protein Chem. 22, 543-554 (2003).

51. Howard, D. R., Herr, J. \& Hollister, R. Using trypsin \& soybean trypsin inhibitor to teach principles of enzyme kinetics. Am. Biol. Teach. 68, 99-104 (2006).

\section{Acknowledgements}

One of the authors A.P.H. is thankful to the fellowship from the University Grants Commission, New Delhi under its MANF (Maulana Azad National Fellowship) scheme [Award No: F1-17.1/2017-18/MANF-2017-18MAH-86211/(SA-III/Website)]. S.S.K. acknowledges the INSPIRE fellowship from the Department of Science and Technology, Government of India, New Delhi. Financial supports from Rajiv Gandhi Science and Technology Commission, Government of Maharashtra, India under Assistance to Science and Technology Applications through University System (Grant No. RGSTC/SUK/JPJ/PAC-07/2019-20) to P.K.P. at the Department of Biochemistry, Shivaji University, Kolhapur. N.R.R. is thankful to UGC- Dr. D. S. Kothari Postdoctoral Fellowship. One of the authors S.A. is thankful to DST-FIST (SR/FST/LSI-629/2015) for ITC facility at IBB, SPPU. Authors are thankful to Mr. Babasaheb Sonwane, CSIR-NCL, Pune for his help in the identification of peptide. Authors are thankful to Dr. M. M. Lekhak, Shivaji University, Kolhapur for his help in the identification of plant.

\section{Author contributions}

Conceived and conducted experiments: A.P.H. and P.K.P. Provided technical ITC support and advice: N.R.R. and S.A. J.S.M. provided technical LC-MS support. Performed the experiments: A.P.H., Analysed the data: A.P.H., S.S.K. and P.K.P. Wrote the original manuscript: A.P.H. and Checked and revised the manuscript: A.P.H. S.S.K. and P.K.P.

\section{Competing interests}

The authors declare no competing interests.

\section{Additional information}

Supplementary Information The online version contains supplementary material available at https://doi.org/ 10.1038/s41598-021-87980-8.

Correspondence and requests for materials should be addressed to P.K.P.

Reprints and permissions information is available at www.nature.com/reprints.

Publisher's note Springer Nature remains neutral with regard to jurisdictional claims in published maps and institutional affiliations. 
(c) (i) Open Access This article is licensed under a Creative Commons Attribution 4.0 International cc) License, which permits use, sharing, adaptation, distribution and reproduction in any medium or format, as long as you give appropriate credit to the original author(s) and the source, provide a link to the Creative Commons licence, and indicate if changes were made. The images or other third party material in this article are included in the article's Creative Commons licence, unless indicated otherwise in a credit line to the material. If material is not included in the article's Creative Commons licence and your intended use is not permitted by statutory regulation or exceeds the permitted use, you will need to obtain permission directly from the copyright holder. To view a copy of this licence, visit http://creativecommons.org/licenses/by/4.0/.

(C) The Author(s) 2021 